\title{
Ecosystem service status and changes of degraded natural reserves - A study from the Changbai Mountain Natural Reserve, China
}

\author{
Dandan $\mathrm{Yu}^{\text {a }}$, Shijie Han ${ }^{\mathrm{b}, *}$ \\ a State Key Laboratory of Urban and Regional Ecology, Research Center for Eco-Environmental Sciences, Chinese Academy of Sciences, 18 Shuangqing Road, \\ Haidian District, Beijing 100085, China \\ ${ }^{\mathrm{b}}$ Key Laboratory of Forest Ecology and Management, Institute of Applied Ecology, Chinese Academy of Sciences, 72 Wenhua Road, Shenyang 110016, China
}

\section{A R T I C L E I N F O}

Article history:

Received 7 August 2015

Received in revised form

24 June 2016

Accepted 28 June 2016

Available online 16 July 2016

Keywords:

Degeneration

Ecosystem services

Sustainable development

Ecosystem management

Nature conservation

\begin{abstract}
A B S T R A C T
The natural reserves are vital to human well-being, but are also highly sensitive to natural and humaninduced disturbances. This paper takes the Changbai Mountain Natural Reserve (CMNR) in Northeastern China as a case to investigate the temporal-spatial variability of ecological capital of natural reserves. The method of Specifications for Assessment of Forest Ecosystem Service in China (LY/T1721-2008) was employed to quantify multiple ecosystem services in the CMNR from 1985 to 2010. Considering the particular requirements of forest ecosystem services and the availability of relevant basic data in the CMNR, this study selected four ecosystem services for 1985, 1997 and 2010 land-use/land-cover conditions: carbon fixation and oxygen release, soil conservation, water conservation and nutrient accumulation. The results show a mix of increases in services (carbon fixation and oxygen release, nutrient accumulation) and decreases in services (water conservation and soil conservation) from 1985 to 2010 . Furthermore, we combined quantified and modeled ecosystem services to generate a suite of indices to identify ecosystem services and land-use/land-cover type that need to be targeted for conservation and mitigation. Our assessment can be used by land managers and policy makers in exploring multiple management scenarios and their implications for ecosystem services in natural reserves.
\end{abstract}

(c) 2016 Elsevier B.V. All rights reserved.

\section{Introduction}

Ecosystem services are direct links between environmental conditions and human well-being (Tallis et al., 2009). The key finding of the UN Millennium Ecosystem Assessment (MA) (2005) was that currently $60 \%$ of the ecosystem services evaluated are being degraded or used unsustainably. The degradation of ecosystem services was recognized as the history root of ecological crisis since 1970s (White, 1967). Therefore, although it is difficult and uncertain, valuation of ecosystem services is important to explore how human well-being may be affected by the degradation (Costanza et al., 1997). In addition, the optimal management of ecosystems also requires the knowledge of the dynamic pattern and status of ecosystem services and an understanding of the interaction among ecosystem processes, structures and functions.

Natural reserves are very critical for the understanding and wise management of the earth and their natural systems. Natural reserves promote the long-term persistence of the widest possible variety of life and maintain the critical ecosystem services on

\footnotetext{
* Corresponding author.

E-mail addresses: ddyu@rcees.ac.cn (D. Yu), sj1102h@163.com (S. Han).
}

which all societies depend, such as the delivery of clean water, the supply of timber and the important role in biodiversity conservation (Jenkins and Joppa, 2009; Lopoukhine et al., 2012; Margules and Pressey, 2000). Although natural reserves alone are not adequate for global conservation efforts, they are the cornerstone of biodiversity conservation (Bruner, 2001; Noss, 1996; Pimm and Lawton, 1998) and the safest strongholds of wilderness (Armesto et al., 1998; Noss, 1996; Soulé and Sanjayan, 1998). The United Nations Educational, Scientific and Cultural Organization (UNESCO) has taken the number and area of natural reserves owned by a country as one of the symbols of civilization and progress. The number and area of natural reserves are soaring. However, what is the underlying status of natural reserves on earth? Recent studies have shown that the protective effectiveness and scientific value of natural reserves are degrading or even disappearing due to mismanagement and conservation politics (Dompka, 1996; Schaller, 1994). The ecological degradation in natural reserves around the world continue to be reported (Bruel et al., 2010; Curran, 2004; Htun et al., 2013; Kiener, 1997; van der Vyver et al., 2012). For example, in China, 40 natural reserves, or about 15\% of the total, such as Shennongjia Natural Reserve, Upper Yangtze Rare and Endemic Fish National Natural Reserve, and 
Changbai Mountain Natural Reserve were substantially degraded due to a combination of swift economic growth and institutional constraints (Liu et al., 2008; Wang et al., 2007b; Yang, 2011). However, quantitative information about the ecological deterioration of natural reserves is scant (Liu et al., 2001; van Schaik and Kramer, 1997), especially there have been few assessments of ecological deterioration from the status and changes in the ecosystem services value. It is not clear how human well-being may be affected by ecological deterioration in natural reserves because there is little research comparing the changes of multiple ecosystem services value.

In order to assess ecological deterioration from the status and changes in the ecosystem services value in natural reserves, this study performed an economic assessment of ecosystem services in the Changbai Mountain Natural Reserve (CMNR) from 1985 to 2010 by 'People's Republic of China Forestry Standard: Forest Ecosystem Service Valuation Norms (LY/T1721-2008)'. The standard was issued by the State Forestry Administration, P.R. China in 2008 (State Forestry Administration of China, 2008). The standard proposes some assessment formulas and reference prices to normalize and guide forest ecosystem services valuation in China (Zhang et al., 2010). This assessment was achieved by exploring the temporal and spatial patterns of the multiple ecosystem services. Specifically, the objectives of this study were to: (1) Quantify the status and changes in the ecosystem services of natural reserves; (2) Assess the ecological degradation in natural reserves; (3) Identify which ecosystem service to target for conservation and mitigation given land-use/land-cover types and which land-use/ land-cover type to target for conservation and mitigation given ecosystem services. Economic assessment of ecological degradation highlighted in this article will provide reference for optimizing meager conservation funds into the research of the causes of observed ecosystem services variation and the most degraded land-use/land-cover types for global ecological degradation in natural reserves.

\section{Materials and methods}

\subsection{Study area}

For conducting this study Changbai Mountain Natural Reserve (CMNR) located in Jilin Province in Northeast China has been selected (Fig. 1). The reserve is typical volcano landscapes and covers an area of about $2000 \mathrm{~km}^{2}$. This district belongs to the north temperate continental monsoon climate characterized by cold weather during the long winter, and short, cool summers. The annual average temperature and precipitation range from $-7{ }^{\circ} \mathrm{C}$ to $3^{\circ} \mathrm{C}$, and $700-1400 \mathrm{~mm}$, respectively. The reserve is noteworthy that its complexity of biota composition and the richness of wild plant and animal species is relatively rare than the same latitude in the northern hemisphere. The reserve has 127 plant genera, including 1477 species of higher plants and 510 species of lower plants, more than 300 vertebrate species (Tao, 1987). Distinct vertical zones in the reserve can be generally described as four natural zones: the mixed forest of broadleaved and Korean pine forest zone $(500-1100 \mathrm{~m})$, the coniferous forest zone (1100 $1800 \mathrm{~m})$, the subalpine Betula ermanii forest zone (1800 $2000 \mathrm{~m}$ ); and the alpine tundra zone (above $2000 \mathrm{~m}$ ) (Wang et al., 1980).

\subsection{Quantifying ecosystem services}

'People's Republic of China Forestry Standard: Forest Ecosystem Service Valuation Norms (LY/T1721-2008)' was used to quantify multiple ecosystem services value in the CMNR and four

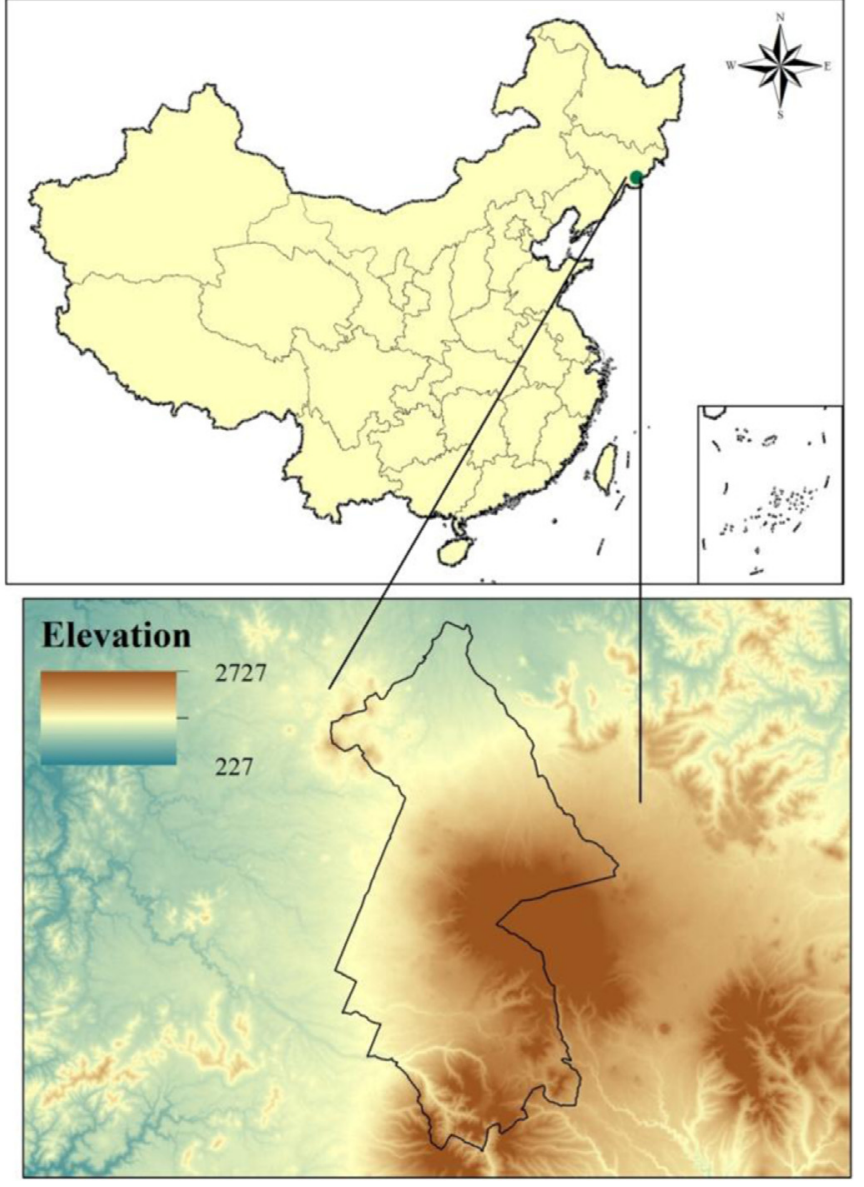

Fig. 1. Location map of the Changbai Mountain Natural Reserve, China.

ecosystem services were selected: carbon fixation and oxygen release, soil conservation, water conservation and nutrient accumulation as relevant to the study area. The four ecosystem services were selected according to the particular requirements of forest ecosystem services and the availability of relevant basic data in the CMNR. The continuous observation dataset by the Ecological Research Station affiliated to the Chinese Forest Ecosystem Research Network (CFERN) were combined to quantify ecosystem services. To compare disparate quantities we need a set of weights that allows us to equate, e.g. the mass of carbon fixation and the mass of water conservation. In this paper the weights are provided by prices. Typically this is done by a picking a single year and using a price inflator (or deflator) to put prices in common year. These are described in more detail below (Tables 1 and 2).

Visual interpretation of Landsat TM images in 1985, 1997 and 2010 was conducted to estimate the proportion of each land-use/ land-cover type in the CMNR. Landsat TM images (2010) of $30 \mathrm{~m}$ resolution in the CMNR were downloaded from internet (http:// earthexplorer.usgs.gov/). Data of the land-use/land-cover in 2010 were extracted from the interpretation of Landsat TM image (2010). Data of the land-use/land-cover in 1997 and 1985 originated from the previous study in the CMNR (Chang et al., 2004). Therefore, data processing of Landsat TM image (2010), which includes preprocessing, training data and classes and accuracy assessment for the classified image, was based on the documentation (Chang et al., 2004). The land-use/land-cover patterns in the CMNR covers tundra, mountain birch forest, evergreen coniferous forest, Korea pine-hardwood forest, aspen and birch forest, larch forest, sparse forest, windthrow area, cut area, residential land, arable land, bare land, and water bodies. Land-use/ 
Table 1

The assessment formulas and parameters set for the assessment of forest ecosystem services.

\begin{tabular}{|c|c|c|c|c|}
\hline Categories & Indicators & Formulas & Parameter description & Data sources \\
\hline \multirow[t]{2}{*}{$\begin{array}{l}\text { Carbon fixation } \\
\text { and Oxygen } \\
\text { release }\end{array}$} & Carbon fixation & $\mathrm{U}_{\mathrm{ci}}=\mathrm{A}_{\mathrm{i}} \mathrm{C}_{\mathrm{c}}\left(1.63 \mathrm{R}_{\mathrm{c}} \mathrm{B}_{\mathrm{i}}+\mathrm{F}_{\mathrm{sc}}\right)$ & $\begin{array}{l}\mathrm{U}_{\mathrm{c}} \text {, is value of carbon fixation of the } \mathrm{i}_{\text {th }} \text { type forest crop, } \\
\$ \mathrm{yr}^{-1} ; \mathrm{A}_{\mathrm{i}} \text {, is area of the } \mathrm{i}_{\mathrm{th}} \text { type forest crop, ha; } \mathrm{B}_{\mathrm{i}} \text {, is the net } \\
\text { productivity production for } \mathrm{i}_{\mathrm{th}} \text { type forest crop, } \mathrm{t} \cdot \mathrm{ha}^{-1} \cdot \mathrm{yr}^{-1} \text {; } \\
\mathrm{C}_{\mathrm{c}} \text {, is the price of carbon fixation per unit mass, } \$ \mathrm{t}^{-1} \mathrm{C} ; \mathrm{R}_{\mathrm{c}} \text {, is } \\
\text { the carbon content in } \mathrm{CO}_{2}, 27.27 \% \text {; } \mathrm{F}_{\mathrm{sci}} \text {, is amount of soil car- } \\
\text { bon fixation per unit area, } \mathrm{t} \cdot \mathrm{ha}^{-1} \cdot \mathrm{yr}^{-1} \text {; }\end{array}$ & $\begin{array}{l}\mathrm{A}_{\mathrm{i}} \text {, is extracted from the interpretation of Landsat TM image } \\
\text { of } 30 \mathrm{~m} \text { resolution, and previous literature records (Chang } \\
\text { et al., 2004); } \mathrm{B}_{\mathrm{i}} \text { is according to previous literature records (Li } \\
\text { et al., 1981). } \mathrm{C}_{\mathrm{c}} \text {, is carbon tax rate proposed by the Swedish } \\
\text { government, } 150 \$ \mathrm{t}^{-1} \mathrm{C} \text {; } \mathrm{F}_{\text {sci }} \text {, is according to previous lit- } \\
\text { erature records (Liu, 2004; Wang et al., 2007a, 2007b, 2006; } \\
\text { Yang and Li, 2003; Zhou et al., 2011) }\end{array}$ \\
\hline & Oxygen release & $U_{o i}=1.19 C_{0} A_{i} B_{i}$ & $\begin{array}{l}\mathrm{U}_{\mathrm{oi}} \text {, is value of oxygen release, } \$ \mathrm{yr}^{-1} ; \mathrm{C}_{\mathrm{o}} \text {, is average oxygen } \\
\text { price, } 125 \$ \mathrm{t}^{-1} ; A_{\mathrm{i}}, \mathrm{B}_{\mathrm{i}} \text {, as above. }\end{array}$ & $\begin{array}{l}C_{o} \text {, is average oxygen price in the spring of } 2007 \text { available at } \\
\text { the website of Ministry of Health of China (http://www. } \\
\text { moh.gov.cn); } A_{i}, B_{i} \text {, as above. }\end{array}$ \\
\hline \multirow[t]{2}{*}{$\begin{array}{l}\text { Soil conserva- } \\
\text { tion }\end{array}$} & Soil fixation & $U_{s i}=A_{i} C_{ \pm}\left(X_{2 i}-X_{1 i}\right) / \rho_{\mathrm{i}}$ & $\begin{array}{l}\mathrm{U}_{\mathrm{si}} \text {, is value of soil conservation, } \$ \mathrm{yr}^{-1} ; \mathrm{C}_{ \pm} \text {, is cost of unit } \\
\text { volume of digging and transporting in } 2007,14.35 ¥ \mathrm{~m}^{-3} \\
\left(1.89 \$ \mathrm{~m}^{-3}\right) ; \mathrm{X}_{1 \mathrm{i}} \text {, is woodland soil erosion modulus, } \mathrm{t} \cdot \mathrm{ha}^{-1} \text {. } \\
\mathrm{yr}^{-1} ; \mathrm{X}_{2 \mathrm{i}} \text {, is non-woodland soil erosion modulus, } \mathrm{t} \cdot \mathrm{ha}^{-1} \text {. } \\
\mathrm{yr}^{-1} ; \rho_{\mathrm{i}} \text {, is woodland bulk density, } \mathrm{t} \mathrm{m}^{-3} ; \mathrm{A}_{\mathrm{i}}, \text { as above. }\end{array}$ & $\begin{array}{l}C_{ \pm} \text {, is calculated by the cost of unit volume of digging and } \\
\text { transporting in } 2002 \text { (Ministry of water resources of the } \\
\text { people's Republic of china, 2002) and China's inflation rates } \\
\text { from } 2002 \text { to } 2007 \text { (http://219.235.129.58/welcome.do); } X_{1} \text {, } \\
\mathrm{X}_{2} \text { are according to previous research (Xue and Bao, 1999); } \\
\rho_{\mathrm{i}} \text {, is according to previous literature records (Pei et al., } \\
1981 \text {; Wang et al., 2007a, 1994, 2007a; Wei et al., 2005; } \\
\text { Xing, 1988); } A_{i} \text {, as above. }\end{array}$ \\
\hline & $\begin{array}{l}\text { Fertilizer } \\
\text { conservation }\end{array}$ & $U_{f i}=A_{i}\left(X_{2 i}-X_{1 i}\right) *\left(N_{i} C_{1} / R_{1}+P_{i} C_{1} / R_{2}+K_{i} C_{2} / R_{3}+M_{i} C_{3}\right)$ & $\begin{array}{l}\mathrm{U}_{\mathrm{fi}} \text { is value of nutrient preserving, } \$ \mathrm{yr}^{-1} ; \mathrm{N}_{\mathrm{i}} \text {, is the average } \\
\text { soil nitrogen content, \%; } \mathrm{P}_{\mathrm{i}} \text {, is the average soil phosphorus } \\
\text { content, \%; } \mathrm{K}_{\mathrm{i}} \text {, is the average soil potassium content, \%; } \mathrm{M}_{\mathrm{i}} \text {, is } \\
\text { the average content of soil organic matter, \%; } \mathrm{R}_{1} \text {, is the ni- } \\
\text { trogen content of DAP (diammonium phosphate), } 14.0 \% ; \mathrm{R}_{2} \text {, is } \\
\text { the phosphorus content of DAP, } 15.01 \% ; \mathrm{R}_{3} \text {, is the potassium } \\
\text { content of } \mathrm{KCl}, 50.0 \% ; \mathrm{C}_{1} \text {, is the price of DAP, } 300 \$ \mathrm{t}^{-1} ; \mathrm{C}_{2} \text {, is } \\
\text { the price of } \mathrm{KCl}, 275 \$ \mathrm{t}^{-1} ; \mathrm{C}_{3} \text {, is the price of the SOM, } 40 \\
\$ \mathrm{t}^{-1} ; \mathrm{A}_{\mathrm{i}}, \mathrm{X}_{1}, \mathrm{X}_{2}, \text { as above. }\end{array}$ & $\begin{array}{l}\mathrm{N}_{\mathrm{i}}, \mathrm{P}_{\mathrm{i}}, \mathrm{K}_{\mathrm{i}} \text {, based on measured data in this study; } \mathrm{M}_{\mathrm{i}} \text {, is ac- } \\
\text { cording to the relationship between soil organic carbon and } \\
\text { organic matter (Bao, 2000); } \mathrm{R}_{1}, \mathrm{R}_{2}, \mathrm{R}_{3} \text { are according to the } \\
\text { national standards of DAP (General Administration of } \\
\text { Quality Supervision, Inspection and Quarantine of the Peo- } \\
\text { ple's Republic of China, 2001); } \mathrm{C}_{1}, \mathrm{C}_{2}, \mathrm{C}_{3} \text { are according to the } \\
\text { average price in the spring of } 2007 \text { available at the website } \\
\text { of the Ministry of Agriculture of the People's Republic of } \\
\text { China (http://www.agri.gov.cn); } \mathrm{A}_{\mathrm{i}}, \mathrm{X}_{1}, \mathrm{X}_{2 \mathrm{i}} \text {, as above. }\end{array}$ \\
\hline \multirow[t]{2}{*}{$\begin{array}{l}\text { Water con- } \\
\text { servation }\end{array}$} & $\begin{array}{l}\text { Hydrological } \\
\text { regulation }\end{array}$ & $U_{v i}=10 C_{v} A_{i}\left(P_{i}-E_{i}-C_{i}\right)$ & $\begin{array}{l}\mathrm{U}_{\mathrm{vi}} \text {, is value of water conservation, } \$ \mathrm{yr}^{-1} ; C_{\mathrm{v}} \text {, is the cost of } \\
\text { reservoir construction unit capacity in } 2007,6.49 \neq \mathrm{m}^{-3} \\
\left(0.85 \$ \mathrm{~m}^{-3}\right) ; \mathrm{P}_{\mathrm{i}} \text {, is annual precipitation, } \mathrm{mm} \mathrm{yr}^{-1} ; \mathrm{E}_{\mathrm{i}} \text {, is eva- } \\
\text { potranspiration, mm yr }{ }^{-1} ; C_{\mathrm{i}} \text {, is surface runoff, } \mathrm{mm} \mathrm{yr}^{-1} ; \mathrm{A}_{\mathrm{i}} \text {, } \\
\text { as above. }\end{array}$ & $\begin{array}{l}C_{\mathrm{V}} \text {, is calculated by the cost of reservoir construction unit } \\
\text { capacity in } 2005 \text { and China's inflation rates from } 2005 \text { to } \\
2007 \text { (http://219.235.129.58/welcome.do); } P_{\mathrm{i}}, \mathrm{E}_{\mathrm{i}}, \mathrm{C}_{\mathrm{i}} \text { are ac- } \\
\text { cording to the consecutive observation data by the Ecolo- } \\
\text { gical Research Station affiliated to CFERN; } \mathrm{A}_{\mathrm{i}} \text {, as above. }\end{array}$ \\
\hline & Water purification & $U_{p i}=10 K A_{i}\left(P_{i}-E_{i}-C_{i}\right)$ & $\begin{array}{l}\mathrm{U}_{\mathrm{pi}} \text {, is value of water decontaminate, } \$ \mathrm{yr}^{-1} ; \mathrm{K} \text {, is the cost of } \\
\text { water decontaminate per unit mass, } 0.26 \$ \mathrm{t}^{-1} ; \mathrm{A}_{\mathrm{i}}, \mathrm{P}_{\mathrm{i}}, \mathrm{E}_{\mathrm{i}}, \mathrm{C}_{\mathrm{i}} \text {, as } \\
\text { above. }\end{array}$ & $\begin{array}{l}\mathrm{K} \text { is according to the average residential water fee in major } \\
\text { cities of } 2007 \text { by gridding method; } A_{\mathrm{i}}, P_{\mathrm{i}}, \mathrm{E}_{\mathrm{i}}, \mathrm{C}_{\mathrm{i}} \text {, as above. }\end{array}$ \\
\hline $\begin{array}{l}\text { Nutrient accu- } \\
\text { mulation }\end{array}$ & $\begin{array}{l}\text { Nutrition } \\
\text { accumulation }\end{array}$ & $U_{n i}=A_{i} B_{i}\left(N_{1 i} \mathcal{G}_{1} / R_{1}+P_{1 i} \mathcal{G}_{1} / R_{2}+K_{1 i} C_{2} / R_{3}\right)$ & $\begin{array}{l}\mathrm{U}_{\mathrm{ni}} \text {, is the value of nutrient element cycling, } \$ \mathrm{yr}^{-1} ; \mathrm{N}_{1 \mathrm{i}} \text {, is } \\
\text { nitrogen content of standing crop, \%; } \mathrm{P}_{1 \mathrm{i}} \text {, is phosphorus con- } \\
\text { tent of standing crop, \%; } \mathrm{K}_{1 \mathrm{i}} \text {, is potassium potassium content } \\
\text { of standing crop, \%; } \mathrm{A}_{\mathrm{i}}, \mathrm{B}_{\mathrm{i}}, \mathrm{R}_{1}, \mathrm{R}_{2}, \mathrm{R}_{3}, \mathrm{C}_{1}, \mathrm{C}_{2} \text {, as above. }\end{array}$ & $\begin{array}{l}N_{1 i}, P_{1 i}, K_{1 i} \text { are according to previous literature records (Wu } \\
\text { et al., 2002); } A_{i}, B_{i}, R_{1}, R_{2}, R_{3}, C_{1}, C_{2} \text {, as above. }\end{array}$ \\
\hline
\end{tabular}

$U_{v e}$ is value of water conservation, $\$ \mathrm{yr}^{-1}$. $\mathrm{C}_{\mathrm{v}}$ is the cost of $\mathrm{C}_{\mathrm{v}}$ is calculated by the cost of reservoir construction unit capacity in 2005 and China's inflation rates from 2005 to potranspiration, $\mathrm{mm} \mathrm{yr}^{-1} ; \mathrm{C}_{\mathrm{i}}$, is surface runoff, $\mathrm{mm} \mathrm{yr}^{-1} ; \mathrm{A}_{\mathrm{i}}$, cording to the consecutive observation data by the Ecoloas above. $\quad$ gical Research Station affiliated to CFERN; $A_{i}$, as above. $\mathrm{U}_{\mathrm{pi}}$, is value of water decontaminate, $\$ \mathrm{yr}^{-1} ; \mathrm{K}$, is the cost of $\mathrm{K}$ is according to the average residential water fee in major water decontaminate per unit mass, $0.26 \$ t^{-1} ; A_{i}, P_{i}, E_{i}, C_{i}$, as cities of 2007 by gridding method; $A_{i}, P_{i}, E_{i}, C_{i}$, as above.

$\mathrm{U}_{\mathrm{ni}}$, is the value of nutrient element cycling, $\$ \mathrm{yr}^{-1} ; \mathrm{N}_{1 \mathrm{i}}$, is $\quad \mathrm{N}_{1 \mathrm{i}}, \mathrm{P}_{1 \mathrm{i}}, \mathrm{K}_{1 \mathrm{i}}$ are according to previous literature records (Wu

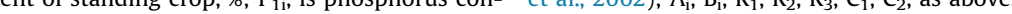
of standing crop, \%; $A_{i}, B_{i}, R_{1}, R_{2}, R_{3}, C_{1}, C_{2}$, as above. 
Table 2

The parameters set for the assessment of forest ecosystem services are according to previous literature records.

\begin{tabular}{|c|c|c|c|c|c|c|c|c|}
\hline land-use/land-cover types & $\mathrm{B}_{\mathrm{i}}$ & $\mathrm{F}_{\mathrm{sci}}$ & $\mathrm{X}_{1}$ & $\mathrm{X}_{2}$ & $\rho_{\mathrm{i}}$ & $\mathrm{N}_{1 \mathrm{i}}$ & $\mathrm{P}_{1 \mathrm{i}}$ & $\mathrm{K}_{1 \mathrm{i}}$ \\
\hline Tundra & 1.14 & 0.37 & 251.40 & 0.46 & 0.84 & 0.63 & 0.13 & 0.24 \\
\hline Mountain birch forest & 5.15 & 0.13 & 222.00 & 0.41 & 0.74 & 0.06 & 0.01 & 0.03 \\
\hline Evergreen coniferous forest & 13.45 & 0.80 & 171.00 & 0.31 & 0.57 & 0.70 & 0.08 & 0.25 \\
\hline Korea pine-hardwood forest & 20.19 & 1.17 & 192.00 & 0.35 & 0.64 & 0.81 & 0.12 & 0.19 \\
\hline Aspen and birch forest & 14.19 & 0.04 & 330.00 & 0.61 & 1.10 & 0.83 & 0.11 & 0.53 \\
\hline Larch forest & 9.50 & 0.54 & 222.00 & 0.41 & 0.74 & 0.60 & 0.09 & 0.30 \\
\hline Sparse forest & 2.38 & 0.59 & 251.40 & 0.46 & 0.84 & 0.13 & 0.01 & 0.01 \\
\hline Windthrow area & - & 0.59 & 195.00 & 0.36 & 0.65 & - & - & - \\
\hline Cut area & 1.71 & 0.40 & 148.80 & 0.27 & 0.50 & 0.01 & 0.02 & 0.05 \\
\hline Residential land & - & - & - & - & - & - & - & - \\
\hline Arable land & - & - & - & - & - & - & - & - \\
\hline Bare land & - & - & - & - & - & - & - & - \\
\hline Water body & - & - & - & - & - & - & - & - \\
\hline
\end{tabular}

land-cover classes in 1985 and 1997 of the CMNR were according to their land-use/land-cover types (Chang et al., 2004), and so it is with land-use/land-cover classes in 2010. The total precision of this land-use/land-cover classification was greater than $87 \%$ (Chang et al., 2004). At finally, we used Raster Calculator tool in ArcGIS 9.3 to calculate the proportion for each land-use/land-cover type.

\subsubsection{Carbon Fixation and Oxygen release}

The forest ecosystem fixes carbon and releases oxygen by the forest vegetation, soil animals and microbes. According to the formula of photosynthesis, the forest vegetation can absorb $1.63 \mathrm{~g}$ $\mathrm{CO}_{2}$ and release $1.19 \mathrm{~g} \mathrm{O}_{2}$ when it accumulates $1.0 \mathrm{~g}$ dry matter. So it is evaluated by two indicators: carbon fixation and oxygen release. The shadow pricing method is used for the calculation of carbon fixation and oxygen release. They are calculated by Eqs. (1) and (2) (Table 1).

\subsubsection{Soil conservation}

The soil conservation of forest functions mainly by reducing the direct impact of water on soil surface to hold soil effectively. Meanwhile, the metabolites in forest constantly affect the physical and chemical structure of soil and participate in the internal energy conversion, material cycle, soil nutrient transformation and migration, and soil structure regulation with the growth of forest. It is evaluated by two indicators: the solidifying soils and the preserving fertilizer. The opportunity-cost method is used for the calculation of soil conservation. They are calculated by Eqs. (3) and (4) (Table 1).

Since soil properties change mainly occurred in the surface soil after land use conversion (Garten and Ashwood, 2002), so soil samples $(0-20 \mathrm{~cm})$ of each land-use/land-cover types between 1985 and 2010 were collected from soil sample room in CFERN. The soil samples have gone through air-dried for a long period of time, so directly passed through 1.0 and $0.25 \mathrm{~mm}$ sieves. Total phosphorus (TP) (molybdenum blue colorimetry) and total potassium (TK) (flame photometry) of the soil samples were determined (Bao, 2000). The dry combustion method was adopted to determine total organic carbon (TOC) and total nitrogen (TN) in soil by Elemental Analyzer (Elementar Vario EL III, Germany).

\subsubsection{Water Conservation}

The function of water conservation is mainly achieved by the interception, absorption, infiltration and redistribution of precipitation, reducing invalid water, and increasing the effective water. It is evaluated by two indicators: adjusting the water quantity and purifying water quality. The shadow pricing method is used for the calculation of water conservation. They are

\section{calculated by Eqs. (5) and (6) (Table 1).}

\subsubsection{Nutrient Accumulation}

During their growth, forest plants absorb ample amounts of nutrients from the atmosphere, soil and precipitation. These nutrients were stored in biological tissue organs through complex biochemical reaction. The market valuation method is used for the calculation of nutrient accumulation. Nutrient accumulation $(\mathrm{N}, \mathrm{P}$, $\mathrm{K}$, and SOM) in living trees can be calculated by Eq. (7) (Table 1).

\subsection{Assessing ecosystem service status and changes}

The study analyzed ecosystem service status and changes by combining quantified and modeled ecosystem services to generate a suite of indices (Leh et al., 2013; Matlock and Morgan, 2011). In order to assess the temporal change of ecosystem services, the study mapped and determined ecosystem service status $\left(E S_{i}\right)$, which was time and land-use/land-cover type-dependent variables that quantify a particular ecosystem service at particular time i. A change in each individual ecosystem service relative to its historic status can be expressed by Eq. (8). In addition, we could combined the average of four ecosystem services changes in each individual land-use/land-cover type ( $\overline{E S C I}$ ) to identify the landuse/land-cover type that is need to target for conservation and mitigation. It can be calculated by Eq. (9):

$E S C I_{x}=\left(E S_{C_{U R_{x i}}}-E S_{R E F_{x j}}\right) / E S_{R E F_{x j}}$

$\overline{E S C I}=\sum E S C I_{x} / \mathrm{N}$

Where $\operatorname{ESCI}_{x}$ is the Ecosystems Services Change Index of service $X$ and represents the relative gain or loss of each of the individual ecosystem services (\%), $E S_{C U R x i}$ and $E S_{R E F x j}$ are the current and referential ecosystem service status values of service $X$ at times $i$ and $\mathrm{j}$, respectively. $\overline{E S C I}$ is the average for all of ESCI of each individual land-use/land-cover type (\%), $\mathrm{N}$ is the number of services being considered represents ecosystem services status of a location. The ecosystem services indices were evaluated at regional scale by setting the ecosystem service values in 1985 as the reference and that in 1997 and 2010 as the current conditions. ESCI $x$ allows for comparison of temporally changes across ecosystem services. A negative/positive ESCI indicates a loss/gain of the ES relative to baseline while negative/positive $\overline{E S C I}$ indicates the average status of cumulative loss/gain of all services over the reference period of each land-use/land-cover type. Each ES index informs management differently, the ESCI provides insight on the temporal change of a particular service and allows us to prioritize individual 


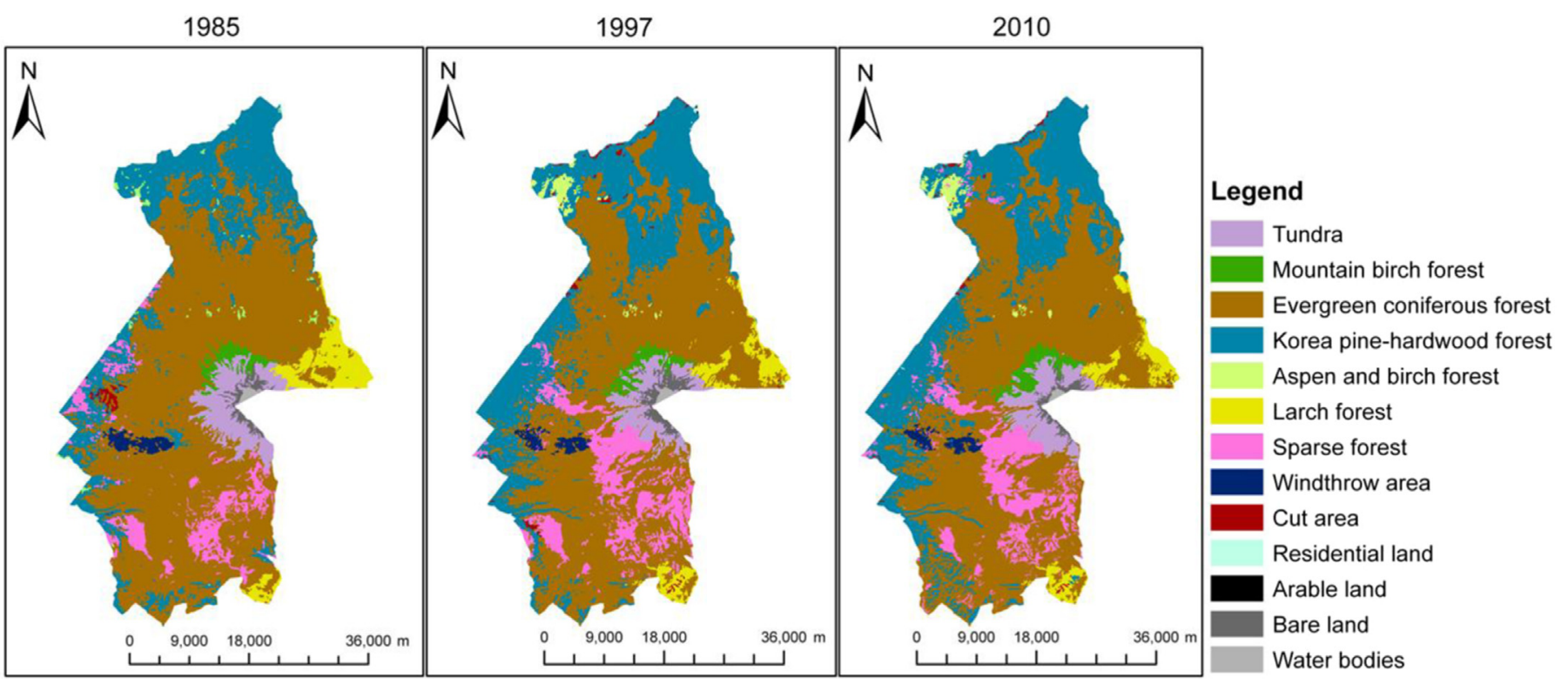

Fig. 2. The land-use/land-cover maps in the CMNR for years 1985, 1997 and 2010.

ecosystem services while $\overline{E S C I}$ allows us to prioritize the land-use/ land-cover type of these services. Because the value of ecosystem services in the natural reserves is determined by the existence value or indirect economic value (supporting and regulating services), which decide the nature of common resource and public property of natural reserves. The carbon fixation and oxygen release, soil conservation, water conservation and nutrient accumulation represent the most important part of indirect economic value (supporting and regulating services) for the CMNR. Therefore, we could combined the average of four ecosystem services changes in each individual land-use/land-cover type ( $\overline{E S C I})$ to identify the land-use/land-cover type that is need to target for conservation and mitigation.

\section{Results}

\subsection{The land-use/land-cover types and their ecosystem services}

Based on the land use assessment, land-use/land-cover change in the CMNR is shown in Fig. 2. In general, the percentage changes of individual land-use/land-cover types in the CMNR from 1985 to 2010 were less than $1 \%$ except to evergreen coniferous forest, Korea pine-hardwood forest and sparse forest (Table 3). The landuse/land-cover area of evergreen coniferous forest and larch forest decreased from 1985 to 1997 but slightly increased from 1997 to 2010, while Korea pine-hardwood forest area, mountain birch forest area, aspen and birch forest area increased steadily throughout (Table 3; Fig. 2). The land-use/land-cover area of tundra area decreased from 1985 to 1997 but increased from 1997 to 2010, whereas cut area, sparse forest area, residential land area and bare land area increased from 1985 to 1997 but decreased from 1997 to 2010 (Table 3; Fig. 2). Ecosystem services followed a similar pattern of distribution to land use/land cover, over $70 \%$ of each of the services was located in the evergreen coniferous forest and Korea pine-hardwood forest, which corresponding areas occupied over $80 \%$ of the study area from 1985 to 2010 (Table 3). Therefore, we suggested that the two kinds of land-use/land-cover types are critical for protecting the continuous supply of ecosystem services.

In particular, for four natural zones (tundra, mountain birch forest, evergreen coniferous forest and Korea pine-hardwood forest zone) in the CMNR, the area of evergreen coniferous forest and tundra declined by $5.99 \%$ (from $60.33 \%$ in 1985 to $54.35 \%$ in 1997) and $1.04 \%$ (from $4.73 \%$ in 1985 to $3.69 \%$ in 1997 ), respectively; while the area of Korea pine-hardwood forest increased by $4.05 \%$ (from $20.82 \%$ in 1985 to $24.86 \%$ in 1997) and that of mountain birch forest slightly increased between 1985 and 1997 (Table 3). Accordingly, the carbon fixation and oxygen release, soil conservation, water conservation and nutrient accumulation of evergreen coniferous forest declined by $6.26 \%, 14.62 \%, 5.31 \%$ and 13.17\% between 1985 and 1997, respectively (Table 3). In contrast, the area of tundra, mountain birch forest, evergreen coniferous forest and Korea pine-hardwood forest increased by $0.26-0.58 \%$ between 1997 and 2010 (Table 3). Accordingly, the percentage changes of individual ecosystem services for the four forest were less than $1 \%$ expect for the soil conservation of evergreen coniferous forest and Korea pine-hardwood forest between 1997 and 2010 (Table 3).

\subsection{Ecosystem services change analysis}

Based on the ESCI and $\overline{E S C I}$, the changes of ecosystem services value and cumulative status of ecosystem services value for different land-use/land-cover types in the CMNR are shown in Fig. 3. On the whole, there was a mix of increase and decrease of ecosystem services across the CMNR (Fig. 3a). Carbon fixation and oxygen release, nutrient accumulation increased from 1997 to 2010. Although both soil conservation and water conservation experienced a decrease relative to 1985 conditions, soil conservation decreased in 1997 but increased in 2010 ( $E S C I=-4.05 \%$ in 1997 and $-1.89 \%$ in 2010) while water conservation decreased from 1997 to 2010 ( $E S C I=-3.95 \%$ in 1997 and $-7.55 \%$ in 2010). In general, the carbon fixation and oxygen release, nutrient accumulation for 2010 increased from 1985 levels by $6.49 \%$ and $1.31 \%$, respectively. While the soil conservation and water conservation for 2010 decreased from 1985 levels by $1.89 \%$ and $7.55 \%$, respectively. To summarize, carbon fixation and oxygen release, nutrient accumulation increased while soil conservation and water conservation decreased. Especially, the decrease of water conservation by 2010 was almost twice times as that by 1997 relative to 1985 conditions.

The $\overline{E S C I}$ for the different land-use/land-cover types in the CMNR ranged from $-33.87 \%$ to $102.48 \%$ in 1997 and from $-25.44 \%$ 
Table 3

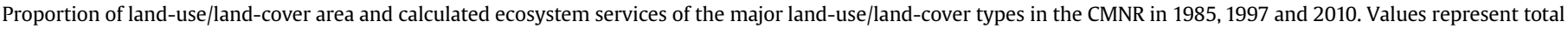
percentage calculated for each land-use/land-cover type.

\begin{tabular}{|c|c|c|c|c|c|}
\hline \multirow[t]{2}{*}{ Land-use/land-cover types } & \multirow[t]{2}{*}{ \% Land-use/land-cover area } & \multicolumn{4}{|c|}{$\%$ of ecosystem service in land-use/land-cover type } \\
\hline & & Carbon fixation and oxygen release & Soil conservation & Water conservation & Nutrient accumulation \\
\hline \multicolumn{6}{|l|}{1985} \\
\hline Tundra & 4.73 & 0.49 & 6.99 & 10.01 & 0.39 \\
\hline Mountain birch forest & 1.34 & 0.52 & 1.47 & 2.11 & 0.04 \\
\hline Evergreen coniferous forest & 60.33 & 62.05 & 62.80 & 48.32 & 60.16 \\
\hline Korea pine-hardwood forest & 20.82 & 32.10 & 20.21 & 26.56 & 35.83 \\
\hline Aspen and birch forest & 0.61 & 0.64 & 0.35 & 0.51 & 0.82 \\
\hline Larch forest & 4.07 & 2.95 & 2.76 & 2.96 & 2.59 \\
\hline Sparse forest & 5.74 & 1.18 & 3.56 & 8.26 & 0.17 \\
\hline Windthrow area & 1.00 & 0.03 & 1.67 & 1.28 & - \\
\hline Cut area & 0.36 & 0.05 & 0.20 & 0.00 & 0.00 \\
\hline Residential land & 0.02 & - & - & - & - \\
\hline Arable land & 0.00 & - & - & - & - \\
\hline Bare land & 0.78 & - & - & - & - \\
\hline Water bodies & 0.19 & - & - & - & - \\
\hline \multicolumn{6}{|l|}{1997} \\
\hline Tundra & 3.69 & 0.38 & 3.74 & 7.74 & 0.23 \\
\hline Mountain birch forest & 1.37 & 0.52 & 1.72 & 2.12 & 0.04 \\
\hline Evergreen coniferous forest & 54.35 & 55.79 & 48.18 & 43.01 & 46.99 \\
\hline Korea pine-hardwood forest & 24.86 & 38.27 & 32.36 & 30.33 & 49.20 \\
\hline Aspen and birch forest & 0.94 & 0.97 & 0.62 & 0.77 & 1.83 \\
\hline Larch forest & 2.94 & 2.13 & 2.17 & 2.12 & 1.30 \\
\hline Sparse forest & 8.95 & 1.83 & 9.73 & 12.77 & 0.40 \\
\hline Windthrow area & 0.90 & 0.03 & 1.11 & 1.14 & - \\
\hline Cut area & 0.53 & 0.08 & 0.37 & 0.00 & 0.00 \\
\hline Residential land & 0.07 & - & - & - & - \\
\hline Arable land & 0.00 & - & - & - & - \\
\hline Bare land & 1.21 & - & - & - & - \\
\hline Water bodies & 0.19 & - & - & - & - \\
\hline \multicolumn{6}{|l|}{2010} \\
\hline Tundra & 3.98 & 0.40 & 4.72 & 8.37 & 0.26 \\
\hline Mountain birch forest & 1.63 & 0.62 & 1.86 & 2.63 & 0.06 \\
\hline Evergreen coniferous forest & 54.96 & 55.80 & 39.76 & 43.85 & 46.92 \\
\hline Korea pine-hardwood forest & 25.15 & 38.29 & 35.31 & 30.53 & 49.13 \\
\hline Aspen and birch forest & 0.98 & 1.01 & 1.54 & 0.81 & 1.97 \\
\hline Larch forest & 3.01 & 2.15 & 3.70 & 2.18 & 1.33 \\
\hline Sparse forest & 8.15 & 1.65 & 11.82 & 10.33 & 0.33 \\
\hline Windthrow area & 0.91 & 0.03 & 1.09 & 1.30 & - \\
\hline Cut area & 0.30 & 0.04 & 0.21 & 0.00 & 0.00 \\
\hline Residential land & 0.05 & - & - & - & - \\
\hline Arable land & 0.00 & - & - & - & - \\
\hline Bare land & 0.83 & - & - & - & - \\
\hline Water bodies & 0.19 & - & - & - & - \\
\hline
\end{tabular}

to $149.67 \%$ in 2010 (Fig. 3b). Relative to the ecosystem service status in 1985, the decrease of ecosystem services occurred in tundra, evergreen coniferous forest, larch forest, windthrow area and cut area while the increase in mountain birch forest, Korea pine-hardwood forest, aspen and birch forest and sparse forest. The tundra, evergreen coniferous forest and larch forest have lost around 20\% of their services by 2010 relative to 1985 conditions, respectively. For those land-use/land-cover types with a negative $\overline{E S C I}$, the $\overline{E S C I}$ in tundra, larch forest and windthrow area in 1997 were less than those in 2010 while the $\overline{E S C I}$ in evergreen coniferous forest showed an opposite trend. For those land-use/landcover types with a positive $\overline{E S C I}$, the $\overline{E S C I}$ in mountain birch forest, Korea pine-hardwood forest, aspen and birch forest in 1997 were less than those in 2010 while the $\overline{E S C I}$ in sparse forest showed an opposite trend. Relative to the ecosystem service status in 1985 , there was a shift in $\overline{E S C I}$ from relative increase in cut area by 1997 to decrease by 2010 ( $\overline{E S C I}=57.24 \%$ in 1997 and $\overline{E S C I}=-11.80 \%$ in 2010). In summary, the ecosystem service status for all land-use/ land-cover types was discrepant, which manifests some land-use/ land-cover types that showed improvements in services (e.g. tundra, mountain birch forest, Korea pine-hardwood forest, aspen and birch forest, larch forest and windthrow area), decreases in services (e.g. evergreen coniferous forest, sparse forest and cut area) and others that experienced little change in services (e.g. windthrow area) from 1997 to 2010 (Fig. 3b). The evergreen coniferous forest should be superior to other forest ecosystems for conservation and mitigation.

\subsubsection{Carbon fixation and oxygen release}

The ESCI for carbon fixation and oxygen release in the CMNR ranged from $-27.79 \%$ to $55.90 \%$ in 1997 and from $-26.15 \%$ to $60.37 \%$ in 2010 (Fig. 4a). Relative to the status of carbon fixation and oxygen release in 1985, the decrease of carbon fixation and oxygen release occurred in tundra, evergreen coniferous forest, larch forest and windthrow area while the increase in mountain birch forest, Korea pine-hardwood forest, aspen and birch forest and sparse forest. For those land-use/land-cover types with a negative ESCI, the ESCI for carbon fixation and oxygen release in tundra, evergreen coniferous forest and larch forest in 1997 were less than those in 2010. Especially, carbon fixation and oxygen release of tundra lost $21.92 \%$ its service between 1985 and 1997 while that lost $15.92 \%$ of its service between 1985 and 2010 (Fig. 4a). It illustrated that the degradation in carbon fixation and oxygen release of tundra has reduced from 1997 to 2010. For those 
(a)

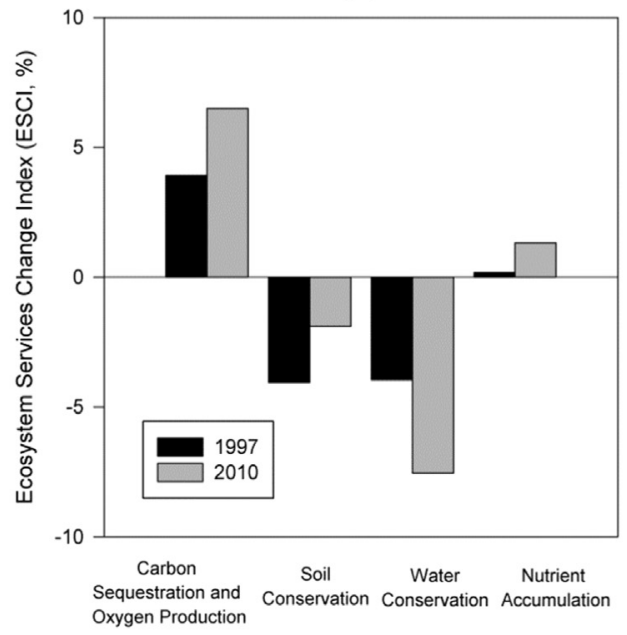

(b)

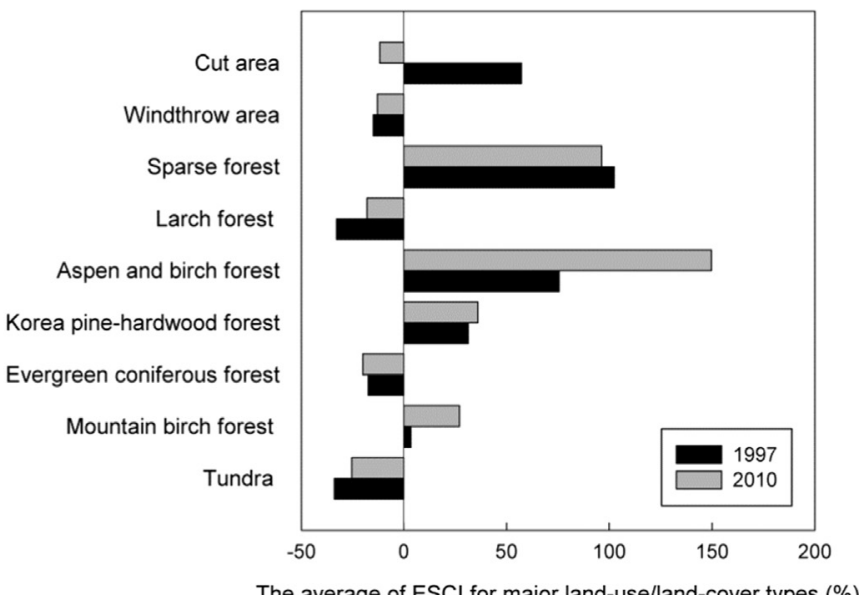

The average of ESCI for major land-use/land-cover types (\%)

Fig. 3. Ecosystem Services Change Index (ESCI) and Ecosystem service status Index ( $\overline{E S C I})$ for major land-use/land-cover types in the CMNR for years 1997 and 2010.

land-use/land-cover types with a positive $E S C I$, the ESCI for carbon fixation and oxygen release in mountain birch forest, aspen and birch forest and Korea pine-hardwood forest in 1997 were less than those in 2010. Relative to the status of carbon fixation and oxygen release in 1985, there was an increase in the ESCI for the service by 1997 but substantial decrease by 2010 in sparse forest and cut area. In particular, relative to that in 1985 , there was a shift in the ESCI for carbon fixation and oxygen release of cut area from relative increase by 1997 to decrease by 2010 ( $E S C I=44.63 \%$ in 1997 and $E S C I=-18.15 \%$ in 2010).

General speaking, the improvements of carbon fixation and oxygen release occurred in tundra, mountain birch forest, aspen and birch forest, and decreased in sparse forest and cut area, and others that experienced little to no change (e.g. evergreen coniferous forest, Korea pine-hardwood forest, larch forest and windthrow area) from 1997 to 2010 (Fig. 4a).

\subsubsection{Soil conservation}

The ESCI for soil conservation in the CMNR ranged from $-48.73 \%$ to $162.45 \%$ in 1997 and from $-37.93 \%$ to $334.31 \%$ in 2010 (Fig. 4b). Relative to the status of soil conservation in 1985, the decrease of soil conservation occurred in tundra, evergreen coniferous forest and windthrow area, while the increase in mountain birch forest, Korea pine-hardwood forest, aspen and birch forest, (a)

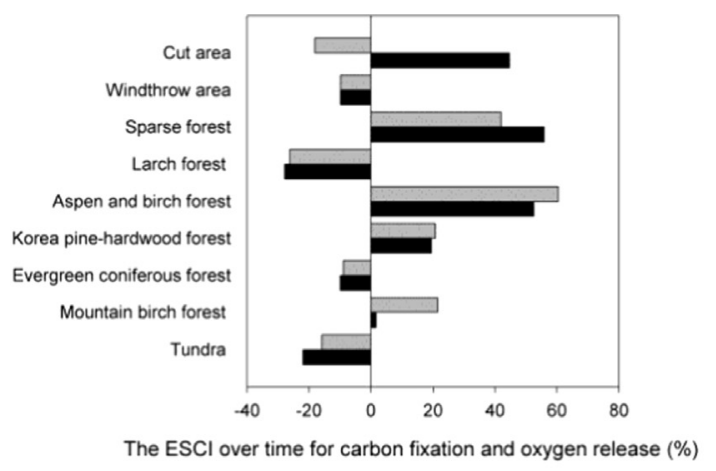

(c)

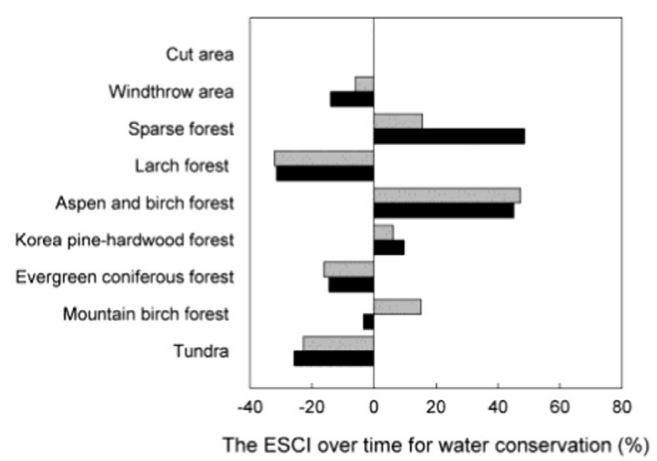

(b)

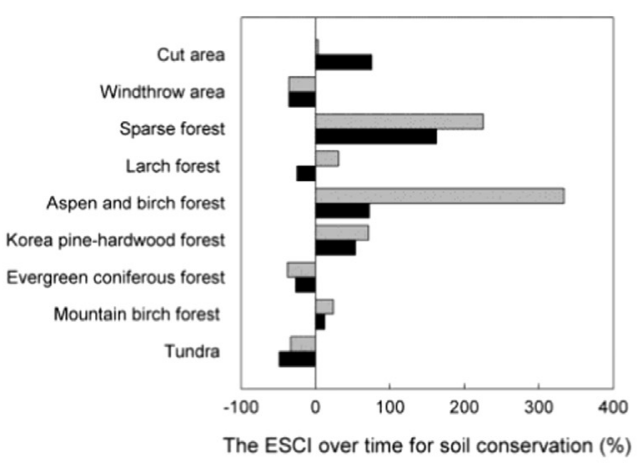

(d)

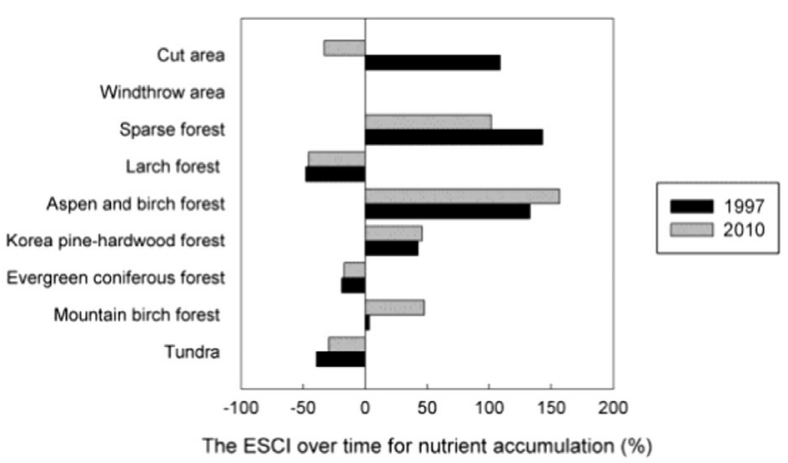

Fig. 4. Ecosystem Services Change Index (ESCI) over time (a. carbon fixation and oxygen release; b. soil conservation; c. water conservation; d. nutrient accumulation). 
larch forest, sparse forest and cut area. Especially, the soil conservation of evergreen coniferous forest lost $26.39 \%$ its service between 1985 and 1997 while that lost 37.93\% of its service between 1985 and 2010. In contrast, the soil conservation of tundra lost $48.73 \%$ its service between 1985 and 1997 while that lost $33.90 \%$ of its service between 1985 and 2010. So this illustrated that the degradation in some land-use/land-cover types is just hanging on while that in others has reduced from 1997 to 2010. Conversely, for those land-use/land-cover types with positive ESCI, the ESCI for the soil conservation in mountain birch forest, aspen and birch forest, Korea pine-hardwood forest and sparse forest in 1997 were less than those in 2010. Relative to the ecosystem service status in 1985, there was an increase in services by 1997 but substantial decrease by 2010 in cut area. In particular, relative to that in 1985, there was a shift in the $E S C I$ for soil conservation of larch forest from relative decrease by 1997 to increase by 2010 $(E S C I=-24.53 \%$ in 1997 and $E S C I=31.38 \%$ in 2010).

General speaking, the improvements of the soil conservation occurred in tundra, mountain birch forest, Korea pine-hardwood forest, aspen and birch forest, larch forest and sparse forest, decreases in evergreen coniferous forest and cut area from 1997 to 2010 (Fig. 4b). The soil conservation of evergreen coniferous forest should be targeted for conservation and mitigation.

\subsubsection{Water conservation}

The ESCI for water conservation in the CMNR ranged from $-32.11 \%$ to $48.54 \%$ for 1997 and 2010 (Fig. 4c). Relative to the status of water conservation in 1985 , the decrease of water conservation occurred in tundra, evergreen coniferous forest, larch forest and windthrow area, while the increase in mountain birch forest, aspen and birch forest, Korea pine-hardwood forest and sparse forest. For those land-use/land-cover types with a negative $E S C I$, the ESCI for water conservation in tundra and windthrow area in 1997 were less than those in 2010 while the evergreen coniferous forest showed an opposite trend (Fig. 4c). It illustrated that the degradation in water conservation of evergreen coniferous forest is just hanging on while the degradation in water conservation of tundra and windthrow area have reduced from 1997 to 2010. Conversely, for those land-use/land-cover types with positive $E S C I$, the $E S C I$ for water conservation in Korea pinehardwood forest and sparse forest in 1997 were much greater than those in 2010 while that in aspen and birch forest was the opposite. In particular, relative to that in 1985 , there was a shift in the ESCI for water conservation of mountain birch forest from relative decrease by 1997 to increase by 2010 (ESCI $=-3.33 \%$ in 1997 and $E S C I=15.15 \%$ in 2010 ).

In general, the improvements of the water conservation occurred in tundra, mountain birch forest, aspen and birch forest and windthrow area, decreases in Korea pine-hardwood forest and sparse forest, and others that experienced little to no change (e.g. evergreen coniferous forest, larch forest) from 1997 to 2010 (Fig. 4c).

\subsubsection{Nutrient accumulation}

The ESCI for nutrient accumulation in the CMNR ranged from $-47.85 \%$ to $143.02 \%$ in 1997 and from $-45.43 \%$ to $156.77 \%$ in 2010 (Fig. 4d). Relative to the status of nutrient accumulation in 1985 , the decrease of nutrient accumulation occurred in tundra, evergreen coniferous forest, larch forest and cut area while the increase in mountain birch forest, aspen and birch forest, Korea pine-hardwood forest and sparse forest. For those land-use/landcover types with a negative ESCI, the ESCI for nutrient accumulation of tundra in 1997 were less than those in 2010 while the ESCI for nutrient accumulation in evergreen coniferous forest and larch forest changed little from 1997 to 2010. It illustrated that the degradation in nutrient accumulation of tundra has reduced from
1997 to 2010. Conversely, for those land-use/land-cover types with a positive $E S C I$, the $E S C I$ for nutrient accumulation in mountain birch forest aspen and birch forest, and Korea pine-hardwood forest in 1997 were much less than those in 2010. Relative to the status of nutrient accumulation in 1985, there was an increase in services by 1997 but substantial decrease by 2010 in sparse forest and cut area. In particular, there was a shift in the ESCI for nutrient accumulation of cut area from relative increase by 1997 to decrease by 2010 ( $E S C I=108.91 \%$ in 1997 and $E S C I=-32.98 \%$ in 2010). In general, the decreases of the nutrient accumulation occurred in sparse forest and cut area while others experienced improvements in the service (e.g. tundra, mountain birch forest, Korea pine-hardwood forest) from 1997 to 2010 (Fig. 4d).

\section{Discussion}

\subsection{The land-use/land-cover change and ecosystem services}

The land use change analysis provided mixed results. This may be the result of a combination of natural disasters and mismanagement and conservation politics within the natural reserves caused the land-use/land-cover adjustment (Yang, 2011). Although the CMNR is on the list of twenty-five national ecological function protected areas for forbidden development zones (http://www. gov.cn/gongbao/content/2013/content_2396624.htm), the construction of true natural reserves in China has not been more substantial legal protection without developing "Reserve Act". The CMNR was stricken by a strong typhoon in 1986 and resulted in large windthrow area, $98 \%$ of whose area was in the core area of the CMNR (Shen, 2010c). A called windthrow collecting policy after the strong typhoon caused that more than 1.7 million cubic meters of logs (1.21 million cubic meters of fallen tree and 0.5 million cubic meters of stumpage) were removed from the CMNR (Shen, 2010c). The remaining small fraction of evergreen coniferous forest was highly fragmented after the small-area clear cutting for seven years and was replaced mainly with secondary birch and aspen forests (Shao et al., 1994). Accordingly, we found that the carbon fixation and oxygen release, soil conservation, water conservation and nutrient accumulation of evergreen coniferous forest declined by $6.26 \%, 14.62 \%, 5.31 \%$ and $13.17 \%$ between 1985 and 1997, respectively (Table 3). Our results may illustrate the effect of land-use/land-cover change as a result of the combination of wind disaster and windthrow collecting policy on ecosystem services of evergreen coniferous forest. In addition, in 2006, the administrative supervision of the CMNR was shifted from the Forestry Bureau to the Tourism Bureau of Jilin Province (Tang et al., 2010). Since then, tourism development has become the most important mission in the CMNR. The Tourism Bureau built an airport on the western slope and opened up all the three roads within CMNR for transporting tourists in 2007 (Tang et al., 2010). Although the three roads that converted from the dirt road into artificial pavement accounted for $0.3 \%$ of the CMNR, the degree of fragmentation of remaining small fraction of evergreen coniferous forest was enhanced (Shen, 2010a, 2010b). It may be the cause for continued declines of soil conservation in evergreen coniferous forest between 1997 and 2010, but further research is needed to tease out the specific cause. For this, we need to assess the effect of natural disturbances (e.g. wind disaster, climate change) and human-induced disturbances (e.g. windthrow collecting, tourism development in natural reserves) on the status and change of the key ecosystem services, and then model and predict these services response to different policy levels using scenarios and models, and explore multiple management scenarios for natural reserves. 


\subsection{The status and change in multiple ecosystem services}

Changes in multiple ecosystems services as a result of natural and human-induced disturbances at different temporal and spatial scales are discrepantly (Bengtsson et al., 2003). For example, Leh et al. (2013) illustrated that there was a mix of increases in services (e.g. nutrient retention), little change in services (e.g. sediment retention) and decreases in services (biodiversity and carbon storage) in West Africa as a result of land-use/land-cover change from 2000 to 2009. Wang et al. (2015) showed that the trade-offs of multiple ecosystem services in the Sanjiang Plain of China were typically manifested by increased water yield and significantly grown food production, which is in contrast with significant losses in carbon stocks and suitable waterbird habitats mainly due to the conversion of land cover from wetland to farmland over the period of 1992-2012. Jiang et al. (2016) confirmed that the soil conservation, water yield, net primary productivity (NPP) and food production in the in the Three-River Headwaters Region, China as a result of climate variability and land cover change, continued to increase from 2000 to 2012. Liu et al. (in press) showed that the carbon stocks and water yield services decreased by $15.48 \%$ and 10.85\%, respectively, from 1976 to 2012 throughout Xishuangbanna prefecture as a whole, and carbon stock and water yield decreased by $45 \%$ and $32 \%$, respectively, from the no plantation to the high plantation zones in 2012 specifically. In the CMNR, nutrient accumulation, carbon fixation and oxygen release increased while water conservation and soil conservation decreased from 1985 to 2010 (Fig. 3a). Especially, the decrease of water conservation by 2010 was almost twice times as that by 1997 relative to 1985 conditions (Fig. 3a). In general, we inferred that changes in multiple ecosystems services that were sensitive to the choice of ecosystem services, time baseline, and temporal and spatial span, are not always consistent. In addition, there is no systematic and standardized comprehensive assessment method of multiple ecosystems services so that it is not always possible to make direct comparisons among those assessment results for different regions. Therefore, we suggested that a comprehensive assessment method of multiple ecosystems services should be developed. The 'People's Republic of China Forestry Standard' adopted in this paper proposes some assessment formulas and reference prices to normalize and guide ecosystem services valuation in China. Although there are still many controversies, deficiencies and problems that need to be further studied, the standard developed the first general framework and provided guidance for the valuation of ecosystem services of ecological degradation in natural reserves in China (Zhang et al., 2010).

\section{Conclusions}

This study is one of the first of its kind in the CMNR on presenting the variation of land-use/land-cover types and valuing ecological degradation from the status and changes in the multiple ecosystem services value. Previous research focused on evaluation of ecosystem services or biodiversity within a given year in the CMNR (Wu et al., 2002; Xue and Bao, 1999). This study contributes to the evolving study of ecological degradation in natural reserves by providing an assessment of the changes and cumulative status of ecosystem services value for different land-use/land-cover types. In order to assess ecological degradation from the status and changes of the ecosystem services value, we valued carbon fixation and oxygen release, soil conservation, water conservation, and nutrient accumulation of the CMNR in Northeastern China between 1985 and 2010. The study used the ESCI and $\overline{E S C I}$ to assess the changes of ecosystem services value and cumulative status of ecosystem services value for different land-use/land-cover types.
The conclusions are as follows:

(1) In the CMNR, the variation of ecosystems services is mixed: carbon fixation and oxygen release, nutrient accumulation increased while water conservation and soil conservation decreased between 1985 and 2010, and the degradation of water conservation was the most apparent and should be targeted for conservation and mitigation.

(2) From the cumulative loss of ecosystem services value for individual land-use/land-cover types, the ecosystem services of tundra, evergreen coniferous forest, larch forest and windthrow area decreased between 1985 and 2010, but the degradation in evergreen coniferous forest is just hanging on while that in the other three has reduced from 1997 to 2010. Therefore, as far as optimizing of meager conservation funds to be concerned, we suggested that evergreen coniferous forest should be targeted for conservation and mitigation. Furthermore, the soil conservation of evergreen coniferous forest should take precedence.

\section{Acknowledgements}

This work was supported by the Science and Technology Service Network Initiative of Chinese Academy of Sciences (No. KFJEW-STS-021-01) and the National Natural Science Foundation of China (No. 41330530).

\section{References}

Armesto, J.J., et al., 1998. Conservation targets in south American temperate forests Science 282 (5392), 1271-1272.

Bao, S., 2000. Soil Agricultural Chemical Analysis, third edition. China Agriculture Press, Beijing.

Bengtsson, J., et al., 2003. Reserves, resilience and dynamic landscapes. AMBIO: A J Human. Environ. 32 (6), 389-396.

Bruel, B.O., et al., 2010. Survival and growth of tree species under two direct seedling planting systems. Restor. Ecol. 18 (4), 414-417.

Bruner, A.G., 2001. Effectiveness of parks in protecting tropical biodiversity. Science 291 (5501), 125-128.

Chang, Y., et al., 2004. Dynamics of forest landscape boundary at Changbai Mountain. Chin. J. Appl. Ecol. 15 (1), 15-20.

Costanza, R., et al., 1997. The value of the world's ecosystem services and natural capital. Nature 387 (6630), 253-260.

Curran, L.M., 2004. Lowland forest loss in protected areas of Indonesian Borneo. Science 303 (5660), 1000-1003.

Dompka, V.E., 1996. Human Proportion, Biodiversity and Protected Areas, Science and Policy Issues. American Association For The Advancement Of Science, Washington, DC.

Garten, C.T., Ashwood, T.L., 2002. Landscape level differences in soil carbon and nitrogen, Implications of soil carbon sequestration. Glob. Biogeochem. Cy 16 (4) 61-1-61-14.

Htun, N.Z., et al., 2013. Changes in determinants of deforestation and forest degradation in Popa Mountain Park, Central Myanmar. J. Environ. Manag. 51 (2), 423-434.

Jenkins, C.N., Joppa, L., 2009. Expansion of the global terrestrial protected area system. Biol. Conserv. 142 (10), 2166-2174.

Jiang, C., et al., 2016. Quantification and assessment of changes in ecosystem service in the Three-River Headwaters Region, China as a result of climate variability and land cover change. Ecol. Indic. 66, 199-211.

Kiener, H., 1997. Windfall and Insects Providing the Impetus and Momentum for Natural Succession in Mountain Forest Ecosystems. Bayerischer Wald National Park, Germany.

Leh, M.D.K., et al., 2013. Quantifying and mapping multiple ecosystem services change in West Africa. Agric. Ecosyst. Environ. 165, 6-18.

Li, W., et al., 1981. Studies on productivity of main ecosystems in Changbai Mountain. In: Wang, Z. (Ed.), Forest Ecosystem Research II. China Forestry Press, Beijing.

Liu, C., 2004. Accumulation of soil organic matter and influential factors on the North Slope of Changbai Mountain. Northeast Forestry University, Harbin, China.

Liu, J., et al., 2001. Ecological Degradation in protected areas, The case of Wolong Nature Reserve for giant pandas. Science 292 (5514), 98-101.

Liu, J., et al., 2008. Ecological and socioeconomic effects of China's policies for ecosystem services. Proc. Natl. Acad. Sci. USA 105, 9477-9482. 
Liu, S., et al., 2016. Ecosystem Services and landscape change associated with plantation expansion in a tropical rainforest region of Southwest China. Ecol. Model. (in press).

Lopoukhine, N., et al., 2012. Protected areas providing natural solutions to 21st century challenges. Surveys Perspect. Integr. Environ. Soc. 5, 117-131.

Margules, C.R., Pressey, R.L., 2000. Systematic conservation planning. Nature 405, 243-253.

Matlock, M.D., Morgan, R., 2011. Ecological Engineering Design, Restoring and Conserving Ecosystem Services. John Wiley \& Sons, Inc, New Jersey.

Millennium Ecosystem Assessment, 2005. Ecosystems and Human Well-being: Synthesis. Island Press, Washington, DC.

Noss, R.F., 1996. Wright, R.G. (Ed.), National Parks and Protected Areas, their Role in Environmental Protection. Blackwell Science, Cambridge, Massachusetts.

Pei, T., et al., 1981. Mathematic model on coefficient of water permeability of forest soil. In: Wang, Z. (Ed.), Forest Ecosystem Research II. China Forestry Press, Beijing.

Pimm, S.L., Lawton, J.H., 1998. Ecology-Panning for biodiversity. Science 279 (5359), 2068-2069.

Schaller, G.B., 1994. The Last Panda. The University Of Chicago Press, Chicago.

Shao, G., et al., 1994. Dynamic simulations of mixed broadleaved-Pinus koraiensis forests in the Changbaishan biosphere reserve of China. Forest Ecol. Manag. 70 (1-3), 169-181.

Shen, X., 2010a. Natural, man-made interference and ecological restoration. Mab. China 3, 30-33.

Shen, X., 2010a. New impacts from tourism development. Mab. China 3, 49-63.

Shen, X., 2010b. A wind disaster turns into man-made calamities. Mab. China 3 , 4-25.

Soulé, M.E., Sanjayan, M.A., 1998. Conservation Targets, Do They Help? Science 279 (5359), 2060-2061.

State Forestry Administration of China, 2008. Specifications for Assessment of Forest Ecosystem Services in China. Standards Press of China, Beijing.

Tallis, H., et al., 2009. Integrating conservation and development in the field, implementing ecosystem service projects. Front. Ecol. Environ. 7 (1), 12-20.

Tang, L., et al., 2010. Forest degradation deepens around and within protected areas in East Asia. Biol. Conserv. 143 (5), 1295-1298.

Tao, Y., 1987. Reservation of the forest resource of Changbai Mountain in relation to human activities. In: Proceedings of an International Symposium, Temperate Forest Ecosystem Management and environmental protection, 5-11 July 1986 Changbai Mountain research station, Academia Sinica, Antu, Jilin Province, Peoples' Republic of China. Yang, H., Wang, Z., Jeffers, J.N.R., Ward, P.A. (Eds.). Institute of Terrestrial Ecology, Grange-over-Sands, Cumbria, UK.

van Schaik, C.P., Kramer, R.A., 1997. Kramer, R., van Schaik, C., Johnson, J. (Eds.), Last Stand, Protected Areas and the Defense of Tropical Biodiversity. Oxford Univ.
Press, New York

van der Vyver, M.L., et al., 2012. Active restoration of woody canopy dominants in degraded South African semi-arid thicket is neither ecologically nor economically feasible. Appl. Veg. Sci. 15 (1), 26-34.

Wang, C., et al., 2007a. Quantifying the soil carbon changes following the afforestation of former arable land. J. Beijing Forest. Univ. 29 (3), 112-119.

Wang, Q., et al., 1994. Physical and chemical properties of soils within larch and larch-ash mixture stands. J. Northeast. Univ. 22 (6), 24-29.

Wang, S., et al., 2007b. Carbon sinks and sources in China's forests during 19012001. J. Environ. Manag. 85 (3), 524-537.

Wang, X., et al., 2006. Comparison of soil respiration in broad-leaved Korean pine forest and reclaimed cropland in Changbai Mountains, China. Chin. J. Plant Ecol. 30 (6), 887-893.

Wang, X., et al., 2007a. Soil respiration in a clear-cut broad-leaved Korean pine forest of Changbai Mountain. Chin. J. Plant Ecol. 31 (3), 355-362.

Wang, X., et al., 2007b. Soil respiration in natural mixed, Betula platyphlla and populus davidiana. primary and secondary broad-leaved Korean pine forest. Chin. J. Plant Ecol. 31 (3), 348-354.

Wang, Z., et al., 2015. Quantifying changes in multiple ecosystem services during 1992-2012 in the Sanjiang Plain of China. Sci. Total Environ. 514, 119-130.

Wang, Z., et al., 1980. Major forest types and the community structure characteristics in the northern slope of Changbai Mountain (I). In: Wang, Z., (Ed.), Forest Ecosystem Study. China Forestry Publishing House, Beijing.

Wei, J., et al., 2005. Carbon storage of alpine tundra ecosystem in Changbai Mountain. Chinese. J. Ecol. 24 (12), 1380-1383.

White, L., 1967. The historical roots of our ecological crisis. Science 155 (03), 1203-1207.

Wu, G., et al., 2002. Forest ecosystem services of Changbai Mountain in China. Sci. China Ser. C. 45 (1), 21-32.

Xing, S., 1988. Forests of Jilin. Jilin Science And Technology Press, Changchun.

Xue, D., Bao, H., 1999. A study on tourist value of biodiversity in Changbai Mountain Biosphere Reserve in Northeast China. J. Nat. Resour. China 14 (2), 140-145.

Yang, D., 2011. China's Environment Development Report 2011. Social Sciences Academic Press, Beijing.

Yang, L., Li, W., 2003. The underground root biomass and C storage in different forest ecosystems of Changbai Mountains in China. J. Nat. Resour. China 18 (2), 204-209.

Zhang, B., et al., 2010. Ecosystem services research in China, Progress and perspective. Ecol. Econ. 69 (7), 1389-1395.

Zhou, L., et al., 2011. Changes in carbon density for three old-growth forests on Changbai Mountain, Northeast China, 1981-2010. Ann. Forest Sci. 68 (5), 953-958. 